\title{
IN VITRO ANTICONVULSANT EFFECT OF ETHYL ACETATE FRACTION OF TITANUS LEAF (LEEA AEQUATA L.) ON ISOLATED COLON
}

\author{
EDY SUWARSO*, NAHITMA GINTING, SUDARMI, VEGI DWINATA MANURUNG
}

Department of Pharmacology, Faculty of Pharmacy, Universitas Sumatera Utara, Medan, Indonesia. Email: parikesit5252@yahoo.co.id

Received: 25 October 2017, Revised: 21 March 2018 and Accepted: 05 February 2018

\section{ABSTRACT}

Objective: The excessive activity of the parasympathetic nervous system in the intestinal smooth muscle is important role in the increased intestinal motility, so antispasmodic medications are needed that can decrease intestinal motility such as atropine. Treatment may also use medicinal plants that are cheaper and easy to obtain, and also believed to have smaller side effects than modern antispasmodic drugs. This study aimed to determine the anticonvulsant or relaxation effects of the ethyl acetate fraction of titanus leaf (EAFTL) against contracted guinea pig colon.

Methods: The parameters measured are smooth muscle relaxation. Before testing, guinea pig colon was equilibrated for 45 min to obtain a stable condition in Tyrode's solution with a temperature of $37^{\circ} \mathrm{C}$ aerated with carbogen gas $\left(\mathrm{O}_{2}: \mathrm{CO}_{2}\right)$ with a ratio of $95 \%: 5 \%$. The relaxing effect of the colon was tested after inducing by acetylcholine chloride; then, each colon was given cumulative concentration of EAFTL and atropine sulfate. The concentration of acetylcholine chloride required to increase the contraction of the guinea pig colon was $1.76 \times 10^{-4} \mathrm{Mol}$. The cumulative concentration of EAFTL given was $0.5-4 \mathrm{mg} / \mathrm{Ml}$ and cumulative concentration of atropine sulfate given was $6.95 \times 10^{-6}-2.08 \times 10^{-2} \mathrm{mg} / \mathrm{Ml}$.

Results: The EAFTL has a relaxing effect. Statistical analysis of EAFTL at a concentration of $4 \mathrm{mg} / \mathrm{Ml}(100.000 \pm 1.7417)$ in reducing the smooth muscle of colon contraction induced by acetylcholine chloride $1.76 \times 10^{-4} \mathrm{Mol}(\mathrm{p}>0.005)$, has not statistically significant compared to that of atropine sulfate $6.95 \times 10^{-3} \mathrm{mg} / \mathrm{Ml}(105.7292 \pm 0.8161)$.

Conclusion: EAFTL has relaxing effect on the smooth muscle of the colon.

Keywords: Titanus leaf, Colon, Guinea pig, Relaxation, In vitro.

(C) 2018 The Authors. Published by Innovare Academic Sciences Pvt Ltd. This is an open access article under the CC BY license (http://creativecommons. org/licenses/by/4. 0/) DOI: http://dx.doi.org/10.22159/ajpcr.2018.v11s1.26614

\section{INTRODUCTION}

Tetanus is one of the potentially fatal causes, characterized by increased spasms of skeletal muscle, one of the manifestations of seizures is the continuous contraction of the muscles in the body or the entire body. Tetanus is caused by the release of toxin compounds by bacterial spores of Clostridium tetani.[11]

The mechanism of tetanus is by inhibiting transmitter in the synapse so that excitatory transmitters will predominate on the synapse, the high excitatory transmitter in this synapse that will increase contraction continuously to cause seizures. The balance between transmitter inhibitory and excitatory transmitter on synapse transmission is essential to maintain the normal functioning of the nervous system. The existence of an imbalance between transmitter inhibitory and excitatory transmitter in the synapse will cause problems in the body. Examples of inhibitory transmitters are GABA, glycine, and nitric oxide, and excitatory transmitters are acetylcholine, histamine, norepinephrine, and serotonin.[13]

The excessive activity of the parasympathetic nervous system in the intestinal smooth muscle is an important role in the increased intestinal motility [6], so antispasmodic medications are needed that can decrease intestinal motility such as atropine. In addition to using antispasmodic drugs, treatment may also use medicinal plants that are cheaper and easy to obtain, and also believed to have smaller side effects than modern antispasmodic drugs.

Titanus leaf (Leea aequata L.) is a plant that is used as a traditional medicine. Its barks and roots are used as astringent, anthelmintic, indigestion, jaundice, chronic fever, and malaria. Its leaves and twigs are used as an antiseptic and treat wounds [3]. The content of titanus leaf is like flavonoids are known to have biological and pharmacological activity tested in vitro as antiallergic, anti-inflammatory, antioxidant, antibacterial, anticancer, and antidiarrheal $[1,2,4]$. While based on study, the ethanol extract titanus leaf has a relaxation effect on the contraction of the isolated guinea pig ileum (smooth muscle) was induced by acetylcholine.

\section{MATERIALS AND METHODS}

\section{Research tool}

The tools used in this study include laboratory glassware, analytical balance (Boeco Germany), animal weights (Presica Geniweigher), a set of organ preparation equipment (Germany), vortex (Boeco Germany), stirrer (Dell), four set organ bath volume $50.0 \mathrm{ml}$ (ML0146/50, Panlab magnet (Bel-Art Products), isometric transducers (MLT0201, Panlab, ADInstruments, Spain), computers (ADInstruments, Spain), microvolume pipette (Socorex, Switzerland) heating and magnetic stirrer (Velp Scientifica, Europe), thermostat (ML0146/50, Panlab, ADInstruments, Spain), PowerLab 15T (T15-0676 series, ADInstruments, Australia), and Quad Bridge Amplifier (serial 224-0448, ADInstruments, Australia).

\section{Materials research}

The samples used in this study were titanus leaf ( $L$. aequata L.), the chemicals used were Tyrode solution (consisting of $\mathrm{NaCl}, \mathrm{KCl}, \mathrm{MgCl} 2$, $\mathrm{NaH} 2 \mathrm{PO} 4, \mathrm{CaCl} 2, \mathrm{NaHCO} 3$, and D-Glucose) (Merck), carbogen gas containing 95\% oxygen and 5\% carbon dioxide (Tri Gases, Medan, Indonesia), acetylcholine $\mathrm{HCl}$ (Sigma, Switzerland), atropine sulfate (Sigma, USA), dimethyl sulfoxide (Merck), and aquadest. This study uses guinea pigs as animal's experiments and the use of animals has been approved by the issuance of Letter of Recommendation of Health Research Ethical Approval from Animal Research Ethics Committees of FMIPA USU with the number: 498/KEPH-FMIPA/2017 [12].

\section{Methods}

Contraction of smooth muscle (colon) induced by acetylcholine

The muscarinic agonists are performed to measure the maximum limit that can be demonstrated to guinea pig colon contractions to obtain 
effective concentration (EC80) by acetylcholine. Measurements are performed gradually with cumulative administration of acetylcholine to obtain concentrations in the organ bath 10-8 to 10-3 Mol. It has been prepared for $45 \mathrm{~min}$ with tyrode solution every $15 \mathrm{~min}$.

The relaxation effect of ethyl acetate fraction of titanus leaf (EAFTL) on colon guinea pig by acetylcholine induction

The isolated colon of guinea pig is contracted by administering $35.2 \mu \mathrm{l}$ of a $2 \times 10^{-1} \mathrm{Mol}$ acetylcholine solution, equivalent with concentration of acetylcholine $1.76 \times 10^{-4} \mathrm{Mol}$ in organ bath. The activity of acetylcholine to increase the contraction of guinea pig colon was done by EAFTL in organ bath is to decrease the contraction. So that it can be obtained the concentration of stratum, i.e., $0.5-4 \mathrm{mg} / \mathrm{Ml}$ EAFTL, has been prepared for $45 \mathrm{~min}$ (with Tyrode solution every $15 \mathrm{~min}$ ).

The relaxation effect of atropine sulfate on colon guinea pig by acetylcholine induction

The isolated colon of the guinea pig is conditioned by a Tyrode solution in the organ bath connected to the isometric transducers. Colon is contracted with $35.2 \mu \mathrm{l}$ of acetylcholine $\left(1.76 \times 10^{-4} \mathrm{Mol}\right)$ in the organ bath. After the contraction obtaining stable then performed the concentration of atropine sulfate.

\section{RESULTS AND DISCUSSION}

The result of contraction smooth muscle (colon isolated from guinea pig) induced by acetylcholine

Contractions triggered by acetylcholine chloride can be observed by observing a change in the smooth muscle (colon isolated) contraction response to the addition of a series acetylcholine chloride concentrations $\left(10^{-8}-10^{-3} \mathrm{Mol}\right)$. The percentage of colon contraction obtained at the stratified with acetylcholine concentration (EC80).

Acetylcholine is a cholinergic agonist which means a drug that promotes cholinergic nerve activity. Acetylcholine will interact with the muscarinic acetylcholine receptor on the cells of the effector organ of the cholinergic nerve such as parietal cells of the stomach, heart muscle, and smooth muscle of the gastrointestinal tract. In the ileum, acetylcholine will interact with muscarinic receptors which will lead to an increase in smooth muscle motility [7]. The results obtained in accordance with the theory obtained (Table 1 and Fig. 1), with the increased concentration of acetylcholine, the intestinal motility will increase.

For more details of Table 1 can be shown in Fig. 1

The result of relaxation effect of EAFTL on isolated colon guinea pig contraction by acetylcholine induction

The relaxation effect of EAFTL against isolated colon (smooth muscle) from guinea pig was performed by contracting the smooth muscle of colon by acetylcholine $1.76 \times 10^{-4} \mathrm{Mol}$, followed by series concentration of $0.5-4 \mathrm{mg} / \mathrm{Ml}$ EAFTL (Table 2 and Fig. 2).

For more details of Table 2 can be shown in Fig. 2 .

The result of relaxation effect of atropine sulfate on isolated colon guinea pig contraction by acetylcholine induction

Testing of atropine sulfate relaxation effect on isolated small intestinal muscle was done by contracting the smooth muscle of colon with acetylcholine $1.76 \times 10^{-4} \mathrm{Mol}$, followed by series of atropine sulfate concentration $6.95 \times 10^{-6}-2.08 \times 10^{-2} \mathrm{mg} / \mathrm{Ml}$ (Table 3 and Fig. 3 ).

For more details of Table 3 can be shown in Fig. 3.

Comparison of \% relaxation of atropine sulfate and EAFTL on contraction of colon by induced acetylcholine

The correlation of percentage of relaxation effect with the concentration of titanus leaf ethyl acetate and the atropine sulfate is not different ( $>0.05)$. The \% relaxation comparison graph of EAFTL and atropine sulfate can be shown in Fig. 4

The comparison of the relaxation effect between atropine sulfate at concentrations of $6.95 \times 10^{-3} \mathrm{mg} / \mathrm{Ml}(105.7292 \pm 0.8161)$ with EAFTL in the administration of $4 \mathrm{mg} / \mathrm{Ml}(100,000 \pm 1.7417)$ for the contraction of the colon induced by acetylcholine showed that the percentage difference relaxation between the two did not significant different (p>0.05). In Fig. 5, it is indicated that EAFTL concentrations of

Table 1: Data of \% contraction by series concentrations of acetylcholine on smooth muscle of the colon

\begin{tabular}{|c|c|c|c|c|c|}
\hline \multirow[t]{2}{*}{ Concentration of acetylcholine (Mol) } & \multicolumn{3}{|c|}{$\%$ Contraction of colon* } & \multirow[t]{2}{*}{ Mean } & \multirow[t]{2}{*}{ Error Standard } \\
\hline & 1 & 2 & 3 & & \\
\hline $1 \times 10^{-8}$ & 32.1428 & 28.5714 & 28.1250 & 29.6131 & 1.2714 \\
\hline $3 \times 10^{-8}$ & 25.0000 & 45.2380 & 28.1250 & 32.7877 & 6.2900 \\
\hline $1 \times 10^{-7}$ & 28.5714 & 45.2380 & 34.3750 & 36.0615 & 4.8844 \\
\hline $3 \times 10^{-7}$ & 28.5714 & 38.0952 & 37.5000 & 34.7222 & 3.0801 \\
\hline $1 \times 10^{-6}$ & 28.5714 & 42.8571 & 37.5000 & 36.3095 & 4.1665 \\
\hline $3 \times 10^{-6}$ & 35.7142 & 47.6190 & 37.5000 & 40.2777 & 3.7065 \\
\hline $1 \times 10^{-5}$ & 39.2857 & 59.5238 & 40.6250 & 46.4782 & 6.5340 \\
\hline $3 \times 10^{-5}$ & 46.4285 & 59.5238 & 50.0000 & 51.9841 & 3.9082 \\
\hline $1 \times 10^{-4}$ & 67.8571 & 71.4285 & 78.1250 & 72.4702 & 3.0094 \\
\hline $3 \times 10^{-4}$ & 92.8571 & 90.4761 & 81.2500 & 88.1944 & 3.5395 \\
\hline $1 \times 10^{-3}$ & 100.0000 & 100.0000 & 100.0000 & 100.0000 & 0 \\
\hline
\end{tabular}

$* \%$ relaxation is calculated from the maximum contraction point achieved by the administration of acetylcholine

Table 2: Data on the relaxation effect of EAFTL on colon contraction by induction of acetylcholine $1.76 \times 10^{-4} \mathrm{Mol}$

\begin{tabular}{|c|c|c|c|c|c|c|c|c|}
\hline \multirow[t]{2}{*}{ Dose of EAFTL (mg/Ml) } & \multicolumn{6}{|c|}{$\%$ Relaxation of colon } & \multirow[t]{2}{*}{ Mean } & \multirow[t]{2}{*}{ Error Standard } \\
\hline & 1 & 2 & 3 & 4 & 5 & 6 & & \\
\hline 0.5 & 38.4616 & 37.2882 & 50.9804 & 59.0909 & 53.9479 & 50.8197 & 48.4314 & 3.5589 \\
\hline 1.5 & 42.8572 & 32.2034 & 76.4706 & 86.3637 & 64.4737 & 65.5738 & 61.3237 & 8.3151 \\
\hline 2.0 & 46.1539 & 47.4577 & 90.1961 & 91.6667 & 75.0000 & 73.7705 & 70.7075 & 8.1468 \\
\hline 2.5 & 49.4506 & 55.9323 & 96.0785 & 93.9394 & 81.5789 & 77.0492 & 75.6715 & 7.8843 \\
\hline 3.0 & 57.1429 & 77.9662 & 100.000 & 95.4546 & 82.8947 & 78.6885 & 82.0245 & 6.1951 \\
\hline 3.5 & 58.2418 & 98.3051 & 100.000 & 96.9697 & 86.8421 & 85.2459 & 87.6008 & 6.3892 \\
\hline 4.0 & 91.2088 & 100.000 & 100.000 & 96.9697 & 97.3684 & 90.1639 & 95.9518 & 1.7497 \\
\hline
\end{tabular}

$* \%$ relaxation is calculated from the maximum contraction point achieved by the administration of acetylcholine 
Table 3: Data on the effects of atropine sulfate relaxation on intestinal contractions by acetylcholine induction $1.76 \times 10^{-4}$ Mol

\begin{tabular}{|c|c|c|c|c|c|c|c|c|}
\hline \multirow[t]{2}{*}{ Concentration of atropine sulfate (mg/Ml) } & \multicolumn{6}{|c|}{$\%$ Relaxation of colon } & \multirow[t]{2}{*}{ Mean } & \multirow{2}{*}{$\begin{array}{l}\text { Error } \\
\text { standard }\end{array}$} \\
\hline & 1 & 2 & 3 & 4 & 5 & 6 & & \\
\hline $6.95 \times 10^{-6}$ & 39.7261 & 37.8379 & 42.7084 & 39.7261 & 24.1379 & 63.6364 & 41.2955 & 5.2048 \\
\hline $6.95 \times 10^{-5}$ & 63.0137 & 91.8919 & 81.2500 & 63.0137 & 75.8621 & 80.0000 & 75.8386 & 4.5953 \\
\hline $2.08 \times 10^{-4}$ & 78.0822 & 94.5946 & 82.2917 & 78.0822 & 87.9311 & 83.6364 & 84.1030 & 2.5812 \\
\hline $6.95 \times 10^{-4}$ & 83.5617 & 97.2973 & 87.5000 & 83.5617 & 94.8276 & 89.0909 & 89.3065 & 2.3361 \\
\hline $2.08 \times 10^{-3}$ & 93.1507 & 100.000 & 88.5417 & 93.1507 & 98.2759 & 100.000 & 95.5198 & 1.8948 \\
\hline $6.95 \times 10^{-3}$ & 94.5206 & 100.000 & 90.6250 & 94.5206 & 98.8276 & 100.000 & 96.4156 & 1.5519 \\
\hline $2.08 \times 10^{-2}$ & 110.958 & 105.405 & 120.833 & 110.958 & 100.000 & 105.454 & 108.935 & 2.9113 \\
\hline
\end{tabular}

$* \%$ relaxation is calculated from the maximum contraction point achieved by the administration of acetylcholine

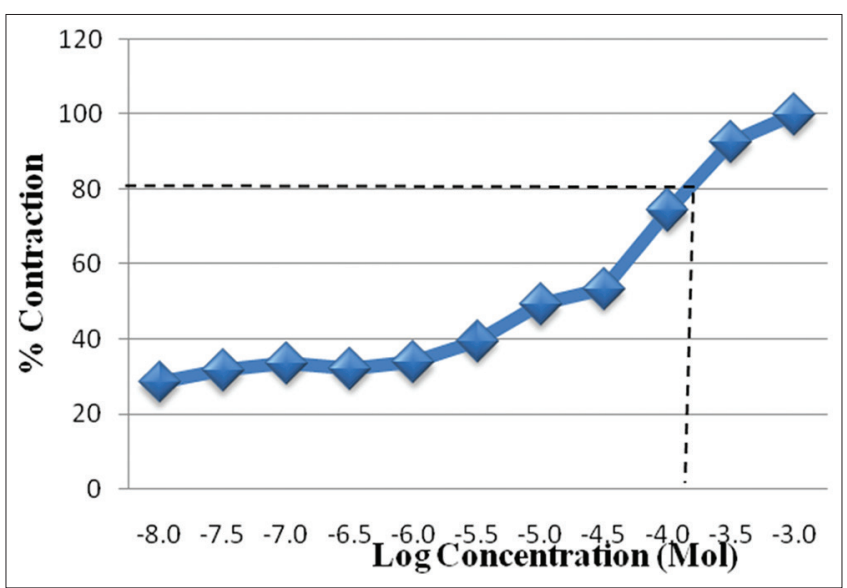

Fig. 1: Graphic \% contraction of smooth muscle (colon isolated) by giving series of acetylcholine concentration, $n=3$

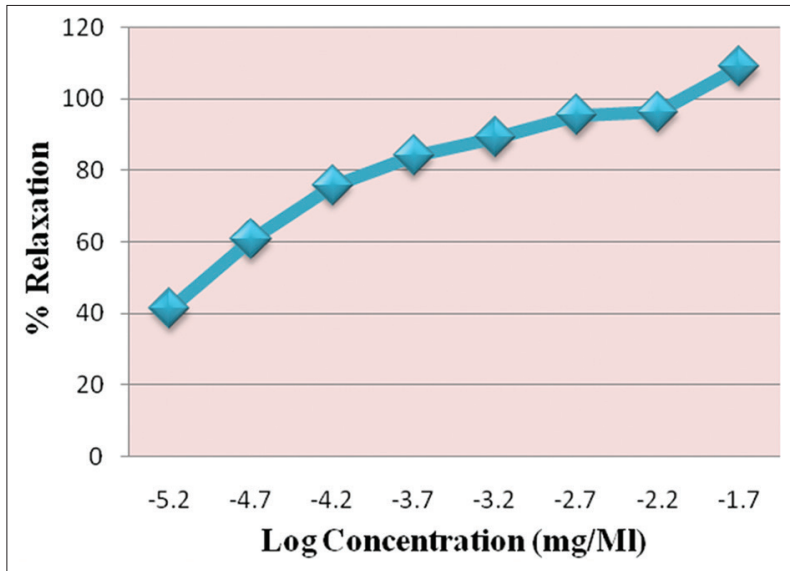

Fig. 3: Graph \% relaxation after the series concentration of atropine sulfate on smooth muscle of colon contracted with acetylcholine $1.76 \times 10^{-4} \mathrm{Mol}, \mathrm{n}=6$

$4 \mathrm{mg} / \mathrm{ml}$ have a capability not much different from the $6.95 \times 10^{-3} \mathrm{mg} / \mathrm{Ml}$ concentration of atropine sulfate in reducing the contraction induced by acetylcholine $1.76 \times 10^{-4} \mathrm{Mol}$.

The existence of a relaxation effect of the EAFTL is probably due to secondary metabolites. Secondary metabolites of L. aequata are alkaloids, glycosides, steroids/terpenoids, flavonoids, and tannins $[1,5,10]$. According to Raihan et al., 2011[9], that Leea indica that has the same family has a strong sedative effect on mice and according to Rahman, et al., 2012, [8] L. indica has a secondary metabolite similar to L. aequata. Therefore, further research is needed on the effect of selective secondary metabolites on the relaxation of smooth muscle of the colon.

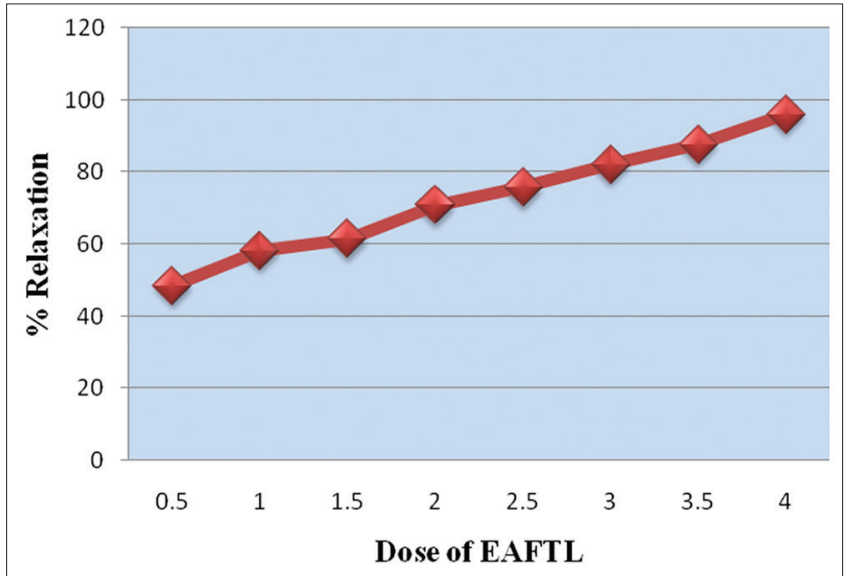

Fig. 2: Graph \% relaxation after the series concentration of EAFTL on smooth muscle of colon contracted with acetylcholine1.76 $\times 10^{-4} \mathrm{Mol}, \mathrm{n}=6$

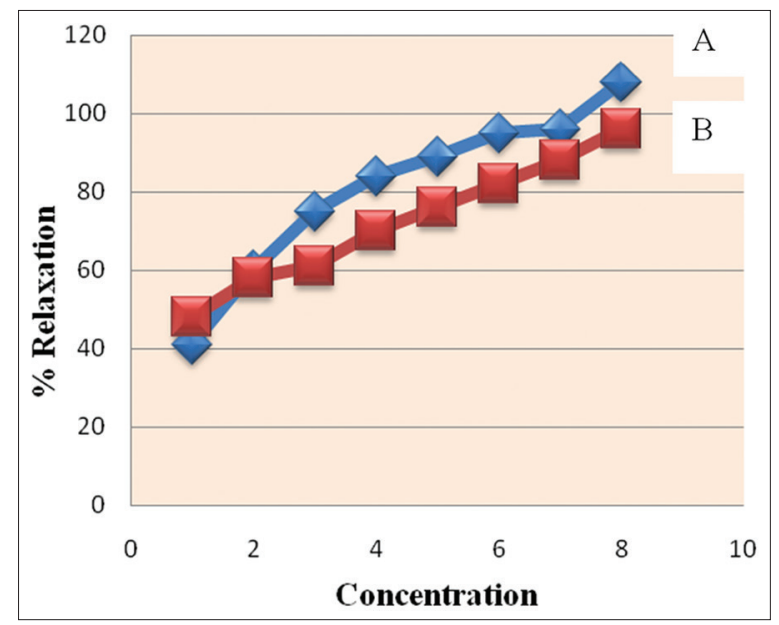

Fig. 4: Graph \% relaxation after series concentration (A) atropine sulfate $\left(1=6.95 \times 10^{-6} ; 2=2.08 \times 10^{-5} ; 3=6.95 \times 10^{-5} ; 4=2.08 \times 10^{-4}\right.$; $\left.5=6.95 \times 10^{-4} ; 6=2.08 \times 10^{-3} ; 7=6.95 \times 10^{-3} ; 8=2.08 \times 10^{-2} \mathrm{mg} / \mathrm{Ml}\right)$ and (B) EAFTL $(1=0.5 ; 2=1 ; 3=1.5 ; 4=2 ; 5=2.5 ; 6=3 ; 7=3.5 ; 8=4 \mathrm{mg} / \mathrm{Ml})$ in the colon contracted with acetylcholine $1.76 \times 10^{-4} \mathrm{Mol}, \mathrm{n}=6$

\section{CONCLUSION}

Based on the study of the relaxation effect of EAFTL (L. aequata L.) to the contraction of colon (smooth muscle of guinea pig) in vitro, it can be concluded

The EAFTL ( $L$. aequata L.) has a relaxant effect on the colon contraction induced by acetylcholine ( $\mathrm{p}>0.05)$. 


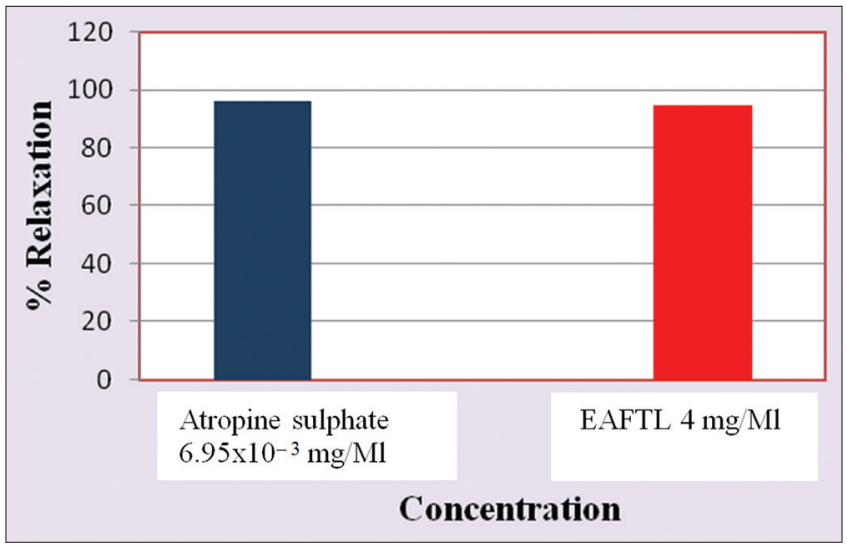

Fig. 5: The \% relaxation value of EAFTL concentration $4 \mathrm{mg} \backslash \mathrm{Ml}$ and atropine sulfate $6.95 \times 10^{-3} \mathrm{mg} / \mathrm{Ml}$ after contracted with acetylcholine $1.76 \times 10^{-4} \mathrm{Mol}(\mathrm{n}=6)$

\section{ACKNOWLEDGMENT}

The authors thank to Dean of the Faculty of Pharmacy USU who has given us the opportunity to conduct independent research under the title "in vitro anticonvulsant effect of EAFTL (L. aequata L.) on isolated colon."

\section{REFERENCES}

1. Farnsworth NR. Biologycal and phytochemical screening of plants. J Pharm Sci 1966;55:263-4.
2. Harborne JB. Phytochemical Methods. Translate by: Kosasih Padmawinata and Iwang Soediro. Phytochemical Methods. Bandung: ITB Press; 1987. p. 147.

3. Khare CP. Indian Medicinal Plants. New Delhi: Springer Science + Business Media, LCC; 2007. p. 366.

4. Kitchen I. Textbook of in vitro Practical Pharmacology. London: Blackwell Scientific Publications; 1984. p. 4.

5. Malinda I. Phytochemical Screening and Antibacterial Activity of Ethanol Extract Titanus Leaf (Leea aequata L.) on Karo Traditional Medicine. Essay. Field. Indonesian: University of North Sumatera; 2015.

6. Neal MJ. In: Safitri A, editor. Medical Pharmacology at a Glance. $5^{\text {th }}$ ed. Jakarta: Erlangga Press; 2005. p. 20-1.

7. Nugroho AE. Pharmacology of Essential Medicines in World Health Pharmaceutical Science. Yogyakarta: Students Literature; 2012. p. 16, 22-3, 26-35, 183 .

8. Rahman MA, Imran TB, dan Islam S. Antioxidative, antimicrobial and cytotoxic effects of the phenolics of Leea indica leaf extract. Saudi J Biol Sci 2012;20:222.

9. Raihan MO, Habib MR, Brishti A, Rahman MM, Saleheen MM, Manna M, et al. Sedative and anxiolytic effects of the methanolic extract of leea indica (Burm. F.) merr. Leaf. Drug Discov Ther 2011;5:185-9

10. Robinson T. The Organic Constituents of High Plant. $6^{\text {th }}$ ed. Translate by: Kosasih Padmawinata. Kandungan Organik Tumbuhan Tinggi. $6^{\text {th }}$ Edisi. Bandung: ITB Press; 1995. p. 154-7.

11. Tiwari T.S. Tetanus. VPD Surveillance Manual. $5^{\text {th }}$ ed. Ch. 161. p. $265-298 ; 2011$.

12. Tyrode MV. The mode of action of some purgative salts. Arch Intern Pharm 1910;17:205-9.

13. Valenzuela CF, Puglia MP, Zucca S. Update on brain pathologyfocus on Neurotransmitter Systems. Alcohol Res Health 2011;34:106-20. 